\title{
The Relationships between Companies and Bank System: An Analysis of Italian Context
}

\author{
Elisa Giacosa ${ }^{1} \&$ Alberto Mazzoleni ${ }^{2}$ \\ ${ }^{1}$ Department of Management, University of Turin, Italy \\ ${ }^{2}$ Department of Economics\&Management, University of Brescia, Italy \\ Correspondence: Elisa Giacosa, Department of Management, University of Turin, Turin, Italy. Tel: \\ 39-011-670-6013. E-mail: elisa.giacosa@unito.it
}

Received: June 21, 2017

doi:10.5539/ijbm.v12n10p1
Accepted: August 30, 2017 Online Published: September 9, 2017

URL: https://doi.org/10.5539/ijbm.v12n10p1

\begin{abstract}
The purpose of our research is to propose to model which could suggest to Italian small and medium companies the best appropriate funding resources to their economic and financial situation. The framework of this paper is represented by Giacosa and Mazzoleni (2016), in which a model classifies the companies into six groups according to different elements, such as attitude to repay financial debts, company's growth, and profitability. The sample is composed of 39.400 Italian companies. In particular, companies could be divided in these categories: i) star companies; ii) companies at the beginning of decline; and iii) companies in crisis.

It emerged that, in a medium-term vision, it's necessary to change the management behavior and to try to reach economic fundamentals expected by the bank system, while in the short-term vision the companies have to learn how to use a non-bank financial instruments.
\end{abstract}

Keywords: funding resources, mini-bonds, alternative financial instruments, small and medium companies, Italian context

\section{Introduction}

The financial structure choices are influenced by both objective and subjective decision-making elements (Giacosa, 2012a and 2012b). Objective elements are linked to the company's needs, as long-term investments must be covered by stable financial sources (for instance, equity or medium-long-term debt), and working capital investments have to be covered by short-term funding sources. On the contrary, the subjective element is linked to the providers of financial resources, which have to be coherent in terms of quantity and costs of enterprises' needs.

Limiting the analysis to funding sources different from equity from current shareholders and trade payables, the parties to whom the companies can recourse are represented by the bank or financial entities different from bank. In Italian banking context, the majority of companies is unprepared to face up the limitation of funding sources, unlike German ones (Mazzoleni, 2016). Therefore, Italian companies have to force a cultural change process, both for developing managerial quality and adapting their economic and financial ratios to market requirements.

The purpose of our research is to propose to model which could suggest to Italian small and medium companies the best appropriate funding resources to their economic and financial situation. The motivation of the research is linked to the current scenario, which is characterized by both banking system's disengagement, cultural companies' unpreparedness and their economic and financial unsuitability, along with some legislative actions lagging behind the companies' needs.

Our framework is represented by Giacosa and Mazzoleni (2016), in which a model classifies the companies into six groups according to different elements, such as attitude to repay financial debts, company's growth, and profitability. In addition, the current research is a development of Giacosa, Mazzoleni, \& Rossi (2006), in which they proposed suitable funding methods for Italian and German medium-sized companies by considering their attitude to repay financial debts, the company's growth, and profitability.

The paper's originality is linked to the companies' current context characterized by a strong financial crisis along with some difficulties in terms of fundraising. Therefore, a model permitting both to understand the company's 
situation and to identify the appropriate funding method should be interested for sustaining its growth and survival.

The paper's structure is the following. The analysis of the literature concerning to financing policy of small and medium-sized companies is focused on the second paragraph, followed by the illustration of the research method. Paragraph four illustrated and discusses the findings, while conclusions, implications and limitations are contained in the last paragraph.

\section{Literature Review}

Economic and financial aspects (Giunta, 2007; Value, 2001) along with elements concerning company's growth (Canals, 2001; Hart \& Mellons, 1970; Goold, 1999; Grandinetti \& Nassimbeni, 2007; Potito, 2013) permit to evaluate and understand the company's situations both in short and medium-long term. Several researchers focused on the definition of the company's financial structure, as the topic has an important role in terms of business management point of view. Topics connected with necessity of self-financing, balance between financial independence and suitable agreements with the third parties were always a subject of various publications.

Several interdependent factors impact the company's situation (Ferrero et al., 2006; Giacosa, 2015), although the literature identified some limitations in their statements (Brealey \& Myers, 1988; Ingram et al., 2002; Lombardi Stocchetti, 2013). In particular, within the literature review, we considered two research branches according to our research goal (Fellnhofer, 2015; Mahérault, 2000; Herrera \& Minetti, 2007): i) the first branch is focused on the company's financial structure and the most appropriate relation between investments and funding; ii) the second one is related to traditional and alternative funding instruments, which could be most appropriate for the specific company's situation.

In terms of the first branch, the dilemma connected with correct choosing of sources of funding has been discussed in numerous publications (Dallocchio et al., 2011; Galbiati, 1999; La Rocca, 2007; Venanzi, 2003; Zazzaro, 2008) as it is considered to be an accelerator of the company's growth and helps to meet its financial requirements (Giacosa \& Guelfi, 2003; Giacosa, 2015; Fazzari et al., 1988; Ferri \& Messori, 2000; Ferri \& Rotondi, 2006; Lang et al., 1996; Machauer \& Weber, 2000; Oliveira \& Fortunato, 2006). Obtained funsing sources should be therefore connected also with appropriate investments (Bertini, 1991; Penrose, 1959).

According to the second branch, a variety of contributions exist, several researchers focused on this topic, especially in terms of different funding instruments' advantages and disadvantages (Venanzi, 1999; Marchi \& Quagli, 1991), also in terms of Italian context (Castronuovo, 2008; Dainelli \& Giunta, 2010; Meles, 2007; Venanzi, 2003) and referring to SMEs (Giacosa, 2015; Giunta, 2005; Pezzini \& Di Cesare, 2003; Unioncamere, 2007). Some part of the present contribution is focused on availability of non-bank funding instruments. As one of such instruments is considered also a listing on a financial market (Anderson \& Reeb, 2003; Belkhir Boujelbene et al., 2011; Rossi, 2015), although it is usually considered as less enthusiastic solution for financing the company's activities (Bracci, 2007; Gualandri \& Schwizer, 2008; Mulkay \& Sassenou, 1995; Osteryoung et al., 1992) seeing that it leads to reduce the control over the company (Gallucci et al., 2012).

As literature has not deepened the problem on non-bank funding instruments for Italian small and medium-sized companies, current research tries to fulfil this gap and it has these scientific contributions: i) the introduction of some alternative non-bank funding instruments permits the company's growth, also impacting on corporate culture and business management; ii) sometimes, the recourse of innovative and alternative funding instruments facilitates the company to reach its expectations. Researchers didn't focus on the evolution of the SMEs' conditions in terms of profitability, growth and financial debt repayment. Therefore, our research encourages companies to improve their economic and financial situation, also thanks to the implications of our paper.

\section{Methodology}

\subsection{The Sample}

The sample is composed of 39.400 Italian companies. In particular, companies could be divided in these categories: i) star companies; ii) companies at the beginning of decline; and iii) companies in crisis. Star companies of the sample are illustrated in the following table, in terms of clusters of sales revenues and number of companies. Each cluster presents the following ratios: EBITDA, CAGR production value, debt/equity ratio, and relationship between financial debt and EBITDA (Table 1). 
Table 1. The star companies in 2015

\begin{tabular}{|l|r|r|r|r|r|}
\hline Sales revenues cluster & \multicolumn{1}{|c|}{ Companies $\mathrm{nr}$} & \multicolumn{1}{c|}{ EBITDA } & $\begin{array}{c}\text { CAGR Production } \\
\text { value }\end{array}$ & \multicolumn{1}{c|}{ Debt/Equity } & \multicolumn{1}{c|}{ Fin. debt/EBITDA } \\
\hline $5-10 \mathrm{M} \ln$ & 2963 & 1143 & $15,64 \%$ & 1,25 & 0,99 \\
\hline $10-50 \mathrm{M} \ln$ & 3216 & 3359 & $16,37 \%$ & 1,23 & 1,07 \\
\hline $50-100 \mathrm{M} \ln$ & 367 & 11225 & $15,94 \%$ & 1,28 & 1,03 \\
\hline $100-200 \mathrm{M} \ln$ & 160 & 22515 & $15,73 \%$ & 1,35 & 1,04 \\
\hline $200 \mathrm{M} \ln -250 \mathrm{M} \ln$ & 25 & 36583 & $13,87 \%$ & 1,21 & 1,08 \\
\hline Total & 6731 & 3391 & $16,01 \%$ & 1,06 \\
\hline
\end{tabular}

Star companies belong to different economic sectors, with certain average production value (Table 2).

Table 2. Star companies and their belonging to different economic sectors

\begin{tabular}{|l|r|r|r|r|}
\hline \multirow{2}{*}{ Sector } & \multicolumn{2}{|c|}{ Companies } & \multicolumn{1}{c|}{ Average production value 2013/2015 } \\
\cline { 2 - 5 } & \multicolumn{1}{|c|}{$\mathrm{Nr}$} & \multicolumn{1}{c|}{$\%$} & & \multicolumn{1}{c|}{} \\
\hline Trade & 115 & $16,6 \%$ & 21717483 & $17,18 \%$ \\
\hline Machinery & 1039 & $15,4 \%$ & 22164841 & $17,53 \%$ \\
\hline Engineering & 718 & $10,7 \%$ & 12370066 & $9,78 \%$ \\
\hline Other manufacturing & 479 & $7,1 \%$ & 8504844 & $6,73 \%$ \\
\hline Costructions & 437 & $6,5 \%$ & 7273961 & $5,75 \%$ \\
\hline Rubber -Plastic & 390 & $5,8 \%$ & 4347148 & $3,44 \%$ \\
\hline Textile & 338 & $5,0 \%$ & 7336173 & $5,80 \%$ \\
\hline Professional Activities & 319 & $4,7 \%$ & 7181970 & $5,68 \%$ \\
\hline Alimentary & 317 & $4,7 \%$ & 4770054 & $3,77 \%$ \\
\hline ICT & 268 & $4,0 \%$ & 4226355 & $3,34 \%$ \\
\hline Transport and storage & 235 & $3,5 \%$ & 3981522 & $3,15 \%$ \\
\hline Petrol-Chemicals & 207 & $3,1 \%$ & 5545872 & $4,39 \%$ \\
\hline Automotive & 154 & $2,3 \%$ & 3242357 & $2,56 \%$ \\
\hline Business services & 151 & $2,2 \%$ & 2709452 & $2,14 \%$ \\
\hline Accommodation and restoration & 137 & $2,0 \%$ & 2193771 & $1,74 \%$ \\
\hline Utilities & 116 & $1,7 \%$ & 1627421 & $1,29 \%$ \\
\hline Pharmaceutical & 86 & $1,3 \%$ & 4352140 & $3,44 \%$ \\
\hline Real estate & 72 & $1,1 \%$ & 769218 & $0,61 \%$ \\
\hline Agriculture & 61 & $0,9 \%$ & 1034246 & $0,82 \%$ \\
\hline Financial assets & 47 & $0,7 \%$ & 526319 & $0,42 \%$ \\
\hline Cultural activities & 43 & $0,6 \%$ & 543305 & $0,43 \%$ \\
\hline n.a. & & $100 \%$ & 126423818 & $100 \%$ \\
\hline Total & & & 5299 & $0,00 \%$ \\
\hline
\end{tabular}

Companies at the beginning of decline are described in the table below (Table 3).

Table 3. The companies at the beginning of decline in 2015

\begin{tabular}{|l|r|r|r|r|r|}
\hline \multicolumn{1}{|c|}{ Sales revenues cluster } & Companies nr & \multicolumn{1}{c|}{ EBITDA } & $\begin{array}{c}\text { CAGR Production } \\
\text { value }\end{array}$ & Debt/Equity & \multicolumn{1}{c|}{ Fin. debt/EBITDA } \\
\hline $5-10 \mathrm{Mln}$ & 2453 & 283 & $3,78 \%$ & 3,98 & 7,15 \\
\hline $10-50 \mathrm{Mln}$ & 2811 & 784 & $4,87 \%$ & 3,39 & 7,05 \\
\hline $50-100 \mathrm{Mln}$ & 345 & 2578 & $3,27 \%$ & 3,10 & 6,61 \\
\hline $100-200 \mathrm{Mln}$ & 143 & 5203 & $3,49 \%$ & 2,69 & 6,51 \\
\hline 200M $\mathrm{Mn}-250 \mathrm{Mln}$ & 20 & 8130 & $4,66 \%$ & 2,86 & 6,72 \\
\hline Total & 5772 & 813 & $4,18 \%$ & 3,27 & 6,88 \\
\hline
\end{tabular}

The companies at the beginning of decline belong to different economic sectors, with certain average production value (Table 4). 
Table 4. The companies at the beginning of decline and their belonging to different economic sectors

\begin{tabular}{|c|c|c|c|c|}
\hline \multirow{2}{*}{ Sector } & \multicolumn{2}{|c|}{ Companies } & \multicolumn{2}{|c|}{ Average production value $2013 / 2015$} \\
\hline & $\mathrm{Nr}$ & $\%$ & & $\%$ \\
\hline Trade & 2442 & $42,3 \%$ & 50419070 & $42,04 \%$ \\
\hline Engineering & 416 & $7,2 \%$ & 8617674 & $7,19 \%$ \\
\hline Alimentary & 408 & $7,1 \%$ & 11695412 & $9,75 \%$ \\
\hline Machinery & 404 & $7,0 \%$ & 8535983 & $7,12 \%$ \\
\hline Costructions & 332 & $5,8 \%$ & 4891739 & $4,08 \%$ \\
\hline Textile & 325 & $5,6 \%$ & 6136465 & $5,12 \%$ \\
\hline Other manufacturing & 324 & $5,6 \%$ & 5988246 & $4,99 \%$ \\
\hline Transport and storage & 270 & $4,7 \%$ & 5090218 & $4,24 \%$ \\
\hline Rubber-Plastic & 238 & $4,1 \%$ & 5010927 & $4,18 \%$ \\
\hline Agriculture & 117 & $2,0 \%$ & 2541624 & $2,12 \%$ \\
\hline Petrol-Chemicals & 105 & $1,8 \%$ & 2874079 & $2,40 \%$ \\
\hline Professional Activities & 87 & $1,5 \%$ & 1643456 & $1,37 \%$ \\
\hline Business services & 67 & $1,2 \%$ & 1338275 & $1,12 \%$ \\
\hline Utilities & 64 & $1,1 \%$ & 1375745 & $1,15 \%$ \\
\hline ICT & 62 & $1,1 \%$ & 1176345 & $0,98 \%$ \\
\hline Automotive & 43 & $0,7 \%$ & 901546 & $0,75 \%$ \\
\hline Accommodation and restoration & 25 & $0,4 \%$ & 479743 & $0,40 \%$ \\
\hline Real estate & 19 & $0,3 \%$ & 319251 & $0,27 \%$ \\
\hline Pharmaceutical & 13 & $0,2 \%$ & 752972 & $0,63 \%$ \\
\hline Cultural activities & 8 & $0,1 \%$ & 118371 & $0,10 \%$ \\
\hline Financial assets & 3 & $0,1 \%$ & 26665 & $0,02 \%$ \\
\hline Total & 5772 & $100 \%$ & 119933806 & $100 \%$ \\
\hline
\end{tabular}

Companies in crisis are described in the table below (Table 5).

Table 5. The companies in crisis in 2015

\begin{tabular}{|l|r|r|r|r|r|}
\hline \multicolumn{1}{|c|}{ Sales revenues cluster } & Companies $\mathrm{nr}$ & EBITDA & CAGR Production value & Debt/Equity & Fin. debt/EBITDA \\
\hline $5-10 \mathrm{M} \ln$ & 2495 & 179 & $1,39 \%$ & 4,26 & 25,98 \\
\hline $10-50 \mathrm{M} \ln$ & 2418 & 479 & $2,35 \%$ & 3,72 & 19,69 \\
\hline $50-100 \mathrm{M} \ln$ & 338 & 1357 & $0,52 \%$ & 3,70 & 20,90 \\
\hline $100-200 \mathrm{M} \ln$ & 152 & 2403 & $0,90 \%$ & 4,97 & 19,90 \\
\hline $200 \mathrm{M} \ln -250 \mathrm{Mln}$ & 33 & 4040 & $5,04 \%$ & 5,16 & 14,76 \\
\hline Total & 5436 & 471 & $1,74 \%$ & 4,03 & 20,77 \\
\hline
\end{tabular}

The companies in crisis belong to different economic sectors, with certain average production value (Table 6).

Table 6. The companies in crisis and their belonging to different economic sectors

\begin{tabular}{|c|c|c|c|c|}
\hline \multirow{2}{*}{ Sector } & \multicolumn{2}{|c|}{ Companies } & \multicolumn{2}{|c|}{ Average production value $2013 / 2015$} \\
\hline & $\mathrm{Nr}$ & $\%$ & & $\%$ \\
\hline Trade & 1722 & $41,67 \%$ & 42932894 & $43,94 \%$ \\
\hline Alimentary & 331 & $8,01 \%$ & 9390521 & $9,61 \%$ \\
\hline Costructions & 294 & $7,12 \%$ & 5681233 & $5,81 \%$ \\
\hline Engineering & 249 & $6,03 \%$ & 6942653 & $7,11 \%$ \\
\hline Machinery & 245 & $5,93 \%$ & 4780492 & $4,89 \%$ \\
\hline Textile & 181 & $4,38 \%$ & 3065100 & $3,14 \%$ \\
\hline Other manufacturing & 174 & $4,21 \%$ & 3153388 & $3,23 \%$ \\
\hline Transport and storage & 171 & $4,14 \%$ & 3179949 & $3,25 \%$ \\
\hline Rubber-Plastic & 154 & $3,73 \%$ & 3773848 & $3,86 \%$ \\
\hline Agriculture & 148 & $3,58 \%$ & 2795499 & $2,86 \%$ \\
\hline Professional Activities & 120 & $2,90 \%$ & 3305752 & $3,38 \%$ \\
\hline Petrol-Chemicals & 64 & $1,55 \%$ & 1891543 & $1,94 \%$ \\
\hline Business services & 62 & $1,50 \%$ & 1991029 & $2,04 \%$ \\
\hline Real estate & 47 & $1,14 \%$ & 822037 & $0,84 \%$ \\
\hline Automotive & 44 & $1,06 \%$ & 1863625 & $1,91 \%$ \\
\hline Utilities & 42 & $1,02 \%$ & 962692 & $0,99 \%$ \\
\hline ICT & 40 & $0,97 \%$ & 607443 & $0,62 \%$ \\
\hline Accommodation and restoration & 27 & $0,65 \%$ & 362850 & $0,37 \%$ \\
\hline Financial assets & 8 & $0,19 \%$ & 110231 & $0,11 \%$ \\
\hline Pharmaceutical & 4 & $0,10 \%$ & 49486 & $0,05 \%$ \\
\hline Cultural activities & 4 & $0,10 \%$ & 44347 & $0,05 \%$ \\
\hline n.a. & 1 & $0,02 \%$ & 4134 & $0,00 \%$ \\
\hline Total & 4132 & $100 \%$ & 97710747 & $100 \%$ \\
\hline
\end{tabular}




\subsection{The Framework}

The framework of the paper is represented by Giacosa and Mazzoleni (2016), which proposes a model of companies classification into six groups according to different elements, such as the attitude to repay financial debts, the company's growth, and the profitability. In addition, we said that our research is a development of Giacosa, Mazzoleni \& Rossi (2006), which proposed a suitable funding method for medium-sized companies by considering their attitude to repay financial debts, the company's growth, and profitability.

Our framework allows to perform analysis taking into consideration the following elements:

- growth the company's growth is measured thanks to CAGR indicator (Compound Annual Growth Rate), which is calculated as follows:

$$
\mathrm{CAGR}=\sqrt{p V_{m} / p V_{n}}-1
$$

Where:

$\mathrm{PVn}, \mathrm{PVm}=$ value of production in years " $\mathrm{n}$ " and " $\mathrm{m}$ ", where $\mathrm{m}>\mathrm{n}$.

- company's profitability:

$$
\text { Profitability in the year " } n "=\text { Ebitda (n)/Production value (n) }
$$

- company's attitude to repay financial debt:

$$
\text { Attitude to repay financial debt in the year } n=\text { Financial Debts (n)/Ebitda (n) }
$$

The framework uses a matrix, which is divided into 6 quadrants. Each of them contains a bubble which represents a group of companies belonging to the quadrant. The bubble's position is influenced by average profitability and financial debt ratio of companies locating in the same quadrant, while its size represents their average companies' growth. Every quadrant has been matched to the most appropriate financial instruments (Figure 1).

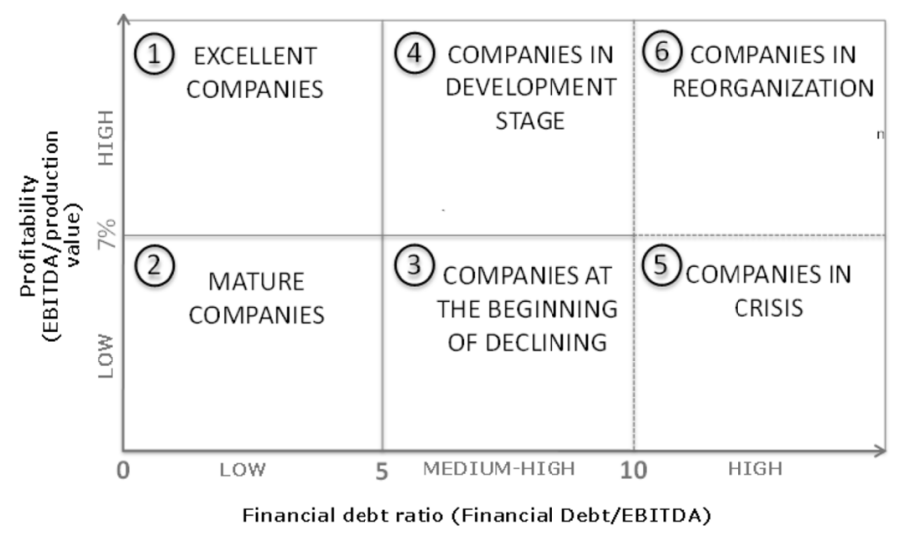

Figure 1. The subjective dimension in financing choices

Subsequently, the companies of our sample have been divided in few categories, according to a credit risk classification model, similar to Moody's, S\&P's and Fitch or Cerved. The ratings from AAA to BBB are referred to safe investment (or investment grade), while the ratings from BBB are defined as speculative grade (with high-risk and more profitable investments). Therefore, the following companies' categories have been identified:

1) Investment grade companies, which are composed of the following companies:

i) Star companies and excellent companies - belonging to the first quadrant, characterized by average profitability above $7 \%$ and average financial debt below 5 . Star companies have access both to bank channel and alternative financial instruments, such as debt (mini-bond or commercial papers) standard or hybrid; quotation on the major or minor markets (AIM); capital market through private equity companies; ii) mature companies - belonging to the second quadrant - which are characterized by a profitability below $7 \%$ but they take advantage of a modest financial debt at the level below 5 . They often recourse to banking channel and also mini-bonds;

2) High risk companies, which contain the following categories: i) companies at the beginning of decline belonging to the third quadrant - characterized by a profitability below $7 \%$ and a long time of financial debts 
repayment between $5-10$ years. They have difficulties in accessing banking channel; therefore, they generally use financial markets (capital and debt); ii) companies in development - belonging to the fourth quadrant - with high average profitability above 7\% and an average financial debt between 5-10 years. Generally, the following funding instruments have been used: private equity operators, hybrid debt or equity instruments, and the quotation on the smaller markets; iii) companies in crisis - belonging to the fifth quadrant and characterized by low profitability (less than 7\%) and a high financial debt more than 10, and subjected to the bankruptcy procedures. They have serious difficulties in obtaining bank loans; therefore, they need another source of financing in non-bank instruments; iv) companies in reorganization - belonging to the sixth quadrant. They are characterized by high profitability (more than 7\%) and financial debt above 10. For that reason, they are also called "distressed companies". They could use both banking channel and non-bank funding instruments.

\section{Findings}

It emerged that:

- First two quadrants is composed of $63 \%$ of Italian companies characterized by very good attitude in repaying financial debts (they repay their debts at least in 5 years);

- Third and fourth quadrant contain $19,1 \%$ of the company with moderate capacity of financial debts repayment (they repay their debts in $5-10$ years);

- $11,9 \%$ of companies has limited attitude of repaying financial debts (in more than 10 years for debt repayment);

- $6 \%$ of companies are characterized by negative EBITDA;

- $38 \%$ companies have profitability higher than $7 \%$;

- $56 \%$ of the companies are characterized by a profitability below $7 \%$.

In addition:

- For star companies, average profitability and capacity to repay financial debts (17,1\% of the sample) are little bit better if compared to other companies belonging to the first quadrant (with a growth below of 5\%). Their growth in three-year period is high $(16,01 \%)$, while the growth of other companies belonging to the same quadrant is not lower than the reference parameter (5\%) and the results are negative (-2,36\%). 32\% of Italian companies belonging to the first quadrant can recourse to both standard or hybrid debt instruments (mini bond or commercial papers), along with capital market, private equity operators, or quotation on a main markets or AIM markets;

- The second quadrant $(30,09 \%)$ is composed of companies with capacity of financial debts repayment in at least 5 years. They are characterized by an average profitability below $7 \%$ in three years;

- $14,6 \%$ of the companies are "companies at the beginning of decline": they recorded profitability of 3,65\%, low ability to repay financial debts (7.13) and the growth in three-year period of 4.18;

- "Companies in development" are about $4,5 \%$ of the sample. They are characterized by high profitability $(13,16 \%)$ and potential growth $(4,07 \%)$, and high debt levels (with an attitude of debt prepayment of 6,82 );

- An attitude of repaying financial debts in at least 10 years characterizes both "companies in crisis" $(10,5 \%$ of the sample) and "companies in reorganization" $(1,4 \%)$. Companies in crisis have an average profitability of 2,09\%, a growth of production value of $1,74 \%$ and limited attitude of financial debts repayment (17,36 years). Companies in reorganization have an high profitability $(24,44 \%)$, a certain attitude to repay financial debts $(18,42$ years) and positive growth $(0,69 \%)$.

Table 7. The composition of the different quadrants of the matrix

\begin{tabular}{|l|r|r|}
\hline & \multicolumn{2}{|c|}{ ITALY } \\
\hline & Nrimprese & \multicolumn{1}{c|}{$\%$} \\
\hline Star companies & 6.731 & $17,08 \%$ \\
\hline Excellent companies & 5.888 & $14,94 \%$ \\
\hline Mature companies & 12.184 & $30,92 \%$ \\
\hline Companies at the beginning of decline & 5.772 & $14,65 \%$ \\
\hline Companies in development & 1.789 & $4,54 \%$ \\
\hline Companies in crisis & 4.132 & $10,49 \%$ \\
\hline Companies in reorganization & 549 & $1,39 \%$ \\
\hline Negative Ebitda & 2.355 & $5,98 \%$ \\
\hline Total & $\mathbf{3 9 . 4 0 0}$ & $\mathbf{1 0 0 \%}$ \\
\hline
\end{tabular}


Table 8. Profitability, debt level and growth of companies in 2013-2015

\begin{tabular}{|l|r|r|r|}
\hline \multirow{2}{*}{} & \multicolumn{3}{|c|}{ ITALY } \\
\cline { 2 - 4 } & PROFITABILITY & DEBT LEVEL & \multicolumn{1}{c|}{ GROWTH } \\
\hline Star companies & $14,96 \%$ & 1,20 & $16,01 \%$ \\
\hline Excellent companies & $14,86 \%$ & 1,31 & $-2,36 \%$ \\
\hline Mature companies & $3,86 \%$ & 1,98 & $5,86 \%$ \\
\hline Companies at the beginning of decline & $3,65 \%$ & 7,13 & $4,18 \%$ \\
\hline Companies in development & $13,16 \%$ & 6,82 & $4,07 \%$ \\
\hline Companies in crisis & $2,09 \%$ & 18,42 & $1,74 \%$ \\
\hline Companies in reorganization & $24,44 \%$ & 17,36 & $0,69 \%$ \\
\hline Negative Ebitda & $-5,54 \%$ & $(6,68)$ & $-5,06 \%$ \\
\hline Total & $7,17 \%$ & 3,70 & $4,16 \%$ \\
\hline
\end{tabular}

In addition, companies with better profitability and growth (with the exception of excellent companies) are characterized by an attitude of repaying financial debts in 1 and 2 years. With the exception of companies in development and in reorganization, they record a low profitability and an ability of debt repayment in a long period (more than 6 years).

\section{Conclusion, Implications and Limitations}

Around $63 \%$ of Italian companies can use bank loans without problems, while $37 \%$ of the companies the bank loan is not the main source of funding.

In a medium-term vision, it's necessary to change the management behavior and to try to reach economic fundamentals expected by the bank system, while in the short-term vision the companies have to learn how to use a non-bank financial instruments.

Different financing instruments could be used by the company: i) debt financing instruments; and ii) capital financing instruments, or iii) a mixed solution. In making the decision process, the company has to taken into account different aspects, such as the sharing of development project of the company, characterized by potential funders/investors, with the purpose to attract their attention to cover the company's needs. In addition, also the way of evaluating the business projects, which is based on historical results which help to assess the company's creditworthiness (in the case of debt financing instruments), and on a combination between past performance and future results (in the case of capital financing instruments assessment).

The financial market (both considering the capital and debt financing market) is characterized by presents development margins in terms of regulatory framework - which facilitate the use of innovative financing instruments - and the number of actors who may operate. The following considerations emerged:

- Companies characterized by high growth rates and higher profitability pursue a prudent policy in terms of banking channels;

- Innovative funding instruments could encourage the companies to change their environment in terms of using only banking channels;

- Considering a short term vision, a banking channel is the most popular way of obtaining financial sources for small and medium-sized companies. However, in a long term vision, it's emerged a relevant change of this aspect especially considering the financing fixed investments;

- Companies using alternative financing instruments (mini bonds) or the listed one are not always belonging to "excellent companies" quadrant. Therefore, access to alternative financing instruments depends not only on business plan but also on the attitude to introduce it to potential funders.

Theoretical and practical implications of the model are the following:

- In terms of theoretical implications, various solutions for small and medium-sized companies have been proposed to improve their performance. In addition, companies belonging to the third and the fifth quadrant need certain corrective actions to improve their condition;

- In terms of practical implications: useful funding instruments adapted to certain group of companies have been introduced. Undertaking paths proposed by the model can positively impact on the companies' economic and financial position, especially when they are also focused at non-bank sources of financing. In addition, it emerged a need of facilitating an access to alternative financing instruments (such as appropriate legislative government's interventions). Also the introduction of rewards and incentive mechanism for those companies could be considered, 
by adopting advanced instruments with the purpose to reduce information asymmetries towards financial community and investors.

The research is characterized by some limitations in different terms:

- According to the analysis, we only used three indicators evaluating the company's economic and financial position (profitability, growth and ability of debt repayment)., despite they represent a strong correlation with the company's performance;

- $\quad$ Our model takes into consideration only quantitative variables. Relevant qualitative factors have not been included (such as the originality of the brand, investment projects and market share).

\section{References}

Anderson, R. C., \& Reeb, D. M. (2003). Founding family ownership and firm performance: Evidence from the S\&P 500. Journal of Finance, 58(3), 1301-1328. https://doi.org/10.1111/1540-6261.00567

Baginski, S. P., \& Hassel, J. M. (2004). Management decision and financial accounting reports. Mason: Thomson South-Western.

Belkhir Boujelbene, N., Bouri, A., \& Prigent, J. L. (2011). Ownership structure and stock market liquidity: evidence from Tunisia. International Journal of Managerial and Financial Accounting, 3(1), 91-109. https://doi.org/10.1504/IJMFA.2011.038365

Bertini, U. (1991). Strategie di sviluppo interno e forme organizzative. In Gozzi, A. (Ed.), La definizione e la valutazione delle strategie aziendali. Milan: Etas.

Bracci, E. (2007). La piccola impresa familiare. In Bracci, E. and Vagnoni, E. (Eds.), Le piccole imprese familiari. Il capitale intellettuale nella gestione del ricambio generazionale. Milan: FrancoAngeli.

Brealey, R. A., \& Myers S. C. (1988). Principi di finanza Aziendale. Milan: McGraw-Hill.

Canals, J. (2001). How to think about corporate growth. European Management Journal, 19(6), 587-598. https://doi.org/10.1016/S0263-2373(01)00084-6

Castronuovo, S. A. (2008). Il settore industriale in Sicilia: dimensione economica e struttura finanziaria. Rome: Bonanno.

Dainelli, F., \& Giunta, F. (2010), Rapporto sulle condizioni economico-finanziarie delle società di capitali toscane 2004-2008. Retrieved from http:/www.fargroup.eu/sites/default/files/Rapporto\%202004-2008.pdf

Dallocchio, M., Tzivelis, D., \& Vinzia, M. A. (2011). Finanza per la crescita sostenibile. Milan: Etas.

Domenichelli, O. (2013). Le determinanti della struttura finanziaria delle imprese: profili teorici ed empirici. Turin: Giappichelli.

Durand, D. (1952). Costs of Debt and Equity Funds for Business: Trends and Problems of Measurement. In Conference on Research in Business Finance (pp. 215-262). National Bureau of Economic Research, New York.

European Central Bank. (2014). Asset Quality Review. Phase 2 Manual. Retrieved from https://www.bankingsupervision.europa.eu/ecb/pub/pdf/assetqualityreviewphase2manual201403en.pdf

Fazzari, S., Hubbard, G., \& Peterson, B. (1988). Financing Constraint and Corporate Investments. Brooking Papers on Economic Activity, 1(1), 141-195. https://doi.org/10.2307/2534426

Fellnhofer, K. (2015). Literature review: investment readiness level of small and medium sized companies. International Journal of Managerial and Financial Accounting, 7(3/4), 268-284. https://doi.org/10.1504/IJMFA.2015.074904

Ferrero, G., Dezzani, F., Pisoni, P., \& Puddu, L. (2006). Analisi di bilancio e rendiconti finanziari. Milan: Giuffré.

Ferri, S., \& Messori, M. (2000). Bank-firm Relationship and Allocative Efficiency in Northeastern and Central Italy and in the South. Journal of Banking and Finance, 24(6), 1067-1095. https://doi.org/10.1016/S0378-4266(99)00118-1

Ferri, S., \& Rotondi, Z. (2006). Does Finance Matter in the Re-specialization of Italy’s Industrial Districts? In Bracchi, G. and Masciandaro, D. (Eds.), Undicesimo Rapporto sul Financial system Italiano. Milan: Bancaria Editrice.

Galbiati, P. (1999). La struttura finanziaria delle imprese. Milan: Egea. 
Gallucci, C., Nave, G., \& Santulli, R. (2012). Nuove modalità di dialogo banca-impresa: il ruolo degli asset familiari. Esperienze d'Impresa, 1(1), 7-24.

Garofalo, G. (1987). La struttura finanziaria: aspetti istituzionali e teorici. Rome: La Sapienza.

Giacosa, E. (2012a). La comunicazione economico-finanziaria d'impresa. Finalità, strumenti e comportamenti attuali e teorici in un modello "ideale” di comunicazione. Turin: Giappichelli.

Giacosa, E. (2012b). Mergers and Acquisitions (M\&As) in the Luxury Business. Milan: McGraw-Hill.

Giacosa, E. (2015). Fabbisogno finanziario e indebitamento nelle piccolo e medie imprese. Milan: FrancoAngeli.

Giacosa, E., \& Guelfi, S. (2003). L'economia delle aziende della net economy. Turin: Giappichelli.

Giacosa, E., \& Mazzoleni, A. (2016). A decision model for the suitable financing for Small and Medium Enterprises. International Journal of Managerial and Financial Accounting, 8(1), 75-96. https://doi.org/10.1504/IJMFA.2016.076667

Giacosa, E., Mazzoleni, A., \& Rossi, M. (2016). The financing methods for small and medium companies: comparison between Italy and Germany. Corporate Ownership \& Control, 13(3), 366-377.

Giunta, F. (2005). Il bilancio. Milan: Apogeo.

Giunta, F. (2007). Analisi di bilancio. Riclassificazioni, indici e flussi. Firenze: Centro Stampa Il Prato.

Goold, M. (1999). The growth imperative. Long Range Planning, 32(1), 127-129. https://doi.org/10.1016/S0024-6301(98)00133-2

Grandinetti, R., \& Nassimbeni, G. (2007). Le dimensioni della crescita aziendale. Milan: FrancoAngeli.

Gualandri, E., \& Schwizer, P. (2008). The Role of the Public Sector', in Gualandri, E. and Venturelli, V. Bridging the Equity Gap for Innovative SMEs. Basingstoke GBR: Palgrave Macmillan Houndmills 145-172.

Hart, P., \& Mellons, J. (1970). Management youth and company growth: a correlation? Management Decision, 4(1), 50-53. https://doi.org/10.1108/eb000925

Herrera, A. M., \& Minetti, R. (2007). Informed Finance and Technological Change: Evidence from Credit Relationship. Journal of Financial Economics, 83(1), 225-269. https://doi.org/10.1016/j.jfineco.2005.12.001

Honjo, Y., \& Harada, N. (2006). SME Policy, Financial Structure and Firm Growth: Evidence from Japan. Small Business Economics, 27(4), 289-300. https://doi.org/10.1007/s11187-005-6703-0

Ingram, R. W., Albright, T. L. and Baldwin, B. A. (2002). Financial Accounting. Information for decisions. Mason: Thomson South-Western.

La Rocca, M. (2008). Corporate governance, struttura finanziaria e valore. Milan: Egea.

La Rocca, M. (Eds.) (2007). Politiche finanziarie d'impresa. Milan: Egea.

Lang, L., Ofek, E., \& Stulz, R. M. (1996). Leverage, Investment and Firm Growth. Journal of Financial Economics, 40(1), 3-29. https://doi.org/10.1016/0304-405X(95)00842-3

Lombardi, S. G. (2013). Valutazione e analisi di bilancio. Milan: Pearson.

Machauer, A., \& Weber, M. (2000). Number of Bank Relationships: An Indicator of Competition, Borrower Quality, or Just Size? Center for Financial Studies, Working Paper Series, 6.

Maggioni, V., Potito, L., \& Viganò, R. (Eds.), (2009), Corporate governance: governo, controllo e struttura finanziaria. Bologna: Il Mulino.

Mahérault, L. (2000). The influence of going public on the investment policy. Family Business Review, 13(1), 71-79. https://doi.org/10.1111/j.1741-6248.2000.00071.x

Marchi, L., \& Quagli, A. (1991). Bilancio gestionale. Evoluzione del sistema contabile e sintesi economica e finanziaria. Milan: Ergon Business Communication.

Meles, A. (2007). Il mercato delle imprese italiane: profili di struttura finanziaria. Naple: E. Albano.

Miles, J. A., \& Ezzel, J. R. (1980). The Weighted Average Cost of Capital, Perfect Capital Markets, and Project Life: A Clarification. The Journal of Financial and Quantitative Analysis, 15(3), 719-730. https://doi.org/10.2307/2330405

Miller, M. R. (1977). Debt and Taxes. The Journal of Finance, 32(2), 261-275. 
Modigliani, F., \& Miller, H. M. (1958). The Cost of Capital, Corporation Finance and the Theory of Investment. The American Economic Review, 48(3), 261-297.

Montalenti, P. (2009). Crisi finanziaria, struttura dell'impresa, corporate governance. Rome: ODC.

Mulkay, B., \& Sassenou, M. (1995). La hiérarchie des financements des investissements des PME. Revue Économique, 8(2), 345-363.

Myers, S. C. (1974). Interactions of Corporate Financing and Investment Decisions - Implications for Capital Budgeting. Journal of Finance, 29(1), 1-25. https://doi.org/10.1111/j.1540-6261.1974.tb00021.x

Oliveira, B., \& Fortunato, A. (2006). Firm Growth and Liquidity Constraints: A Dynamic Analysis. Small Business Economics, 27(2), 139-156. https://doi.org/10.1007/s11187-006-0006-y

Osteryoung, J. S., Constand, R. L., \& Nast, D. A. (1992). Financial ratios in large public and small private firms. Journal of Small Business Management, 30(3), 35-46.

Penrose, E. T. (1959). The Theory of the Growth of the Firm., New York: Oxford University Press.

Pezzini, A., \& Di Cesare, M. (2003). Le piccole e medie imprese in Europa. Catanzaro: Rubbettino Editore.

Potito, L. (2013). Le operazioni straordinarie nell'economia delle imprese. Turin: Giappichelli.

Rossi, M. (2014b). Capital budgeting in Europe: Confronting theory with practice. International Journal of Managerial and Financial Accounting, 6(4), 341-356. https://doi.org/10.1504/IJMFA.2014.066403

Rossi, M. (2015). The efficient market hypothesis and calendar anomalies: a literature review. International Journal of Managerial and Financial Accounting, 7(3/4), 285-296. https://doi.org/10.1504/IJMFA.2015.074905

Unioncamere. (2007). Le piccole e medie imprese nell'economia italiana. Rapporto 2007. Il dinamismo della ristrutturazione. Milan: FrancoAngeli.

Value, B. (2001). Guide to Analysing Companies. London: The Economist, Profile Books.

Venanzi, D. (1999). La scelta della struttura finanziaria: teoria ed evidenza empirica. Turin: Italy.

Venanzi, D. (2003). Le decisioni di struttura finanziaria delle imprese italiane. Perugia: Morlacchi.

Venanzi, D. (2010). Il puzzle della struttura finanziaria. Milan: Pearson Prentice Hall.

Zazzaro, A. (2008). I vincoli finanziari alla crescita delle imprese. Rome: Cacucci.

\section{Copyrights}

Copyright for this article is retained by the author(s), with first publication rights granted to the journal.

This is an open-access article distributed under the terms and conditions of the Creative Commons Attribution license (http://creativecommons.org/licenses/by/4.0/). 